Araştırma Makalesi - Research Article

\title{
Monotipik Steveniella satyrioides türünün anatomik morfolojik ve mikromorfolojik özellikleri
}

\author{
Mustafa Kemal AKBULUT ${ }^{1 *}$, Şenay SÜNGÜ ŞEKER ${ }^{2}$, Gülcan ŞENEL ${ }^{3}$ \\ Geliş / Received: 07/08/2019 \\ Revize / Revised: 07/12/2019 \\ Kabul / Accepted: 08/12/2019
}

$\overline{\mathbf{O Z Z}}$

Çalışmamızda angiospermlerin en büyük iki familyasından birisi olan Orchidaceae familyasına ait Türkiye'de yayılış gösteren Steveniella satyrioides (Stev.) Schltr. türü morfolojik, anatomik ve mikromorfolojik yönden incelenmiştir. S. satyrioides monotipik bir türdür ve çiçek yapısı Orchis cinsine ait türler ile benzerlik göstermektedir. Anatomik incelemelerde örneklerin kök, gövde ve yaprağından mikrotomla enine kesitler alınmıştır. Morfolojik incelemeler için arazide gözlemler yapılmış ve toplanan örnekler üzerinde ölçümler yapılmıştır. Mikromorfolojik incelemelerde herbaryum örneklerinden alınan yapraklar kullanılarak taramalı elektron mikroskop (SEM) çekimleri yapılmıştır. Anatomik incelemelerde kökte en dış kısımda tek tabakalı ekzodermis hücreleri ve merkezde öz bölgesine rastlanmıştır. Ksilem kol sayısı ortalama 8-9 olarak belirlenmiştir. Gövde de perivasküler sklerenkimatik kına, yapraklarda ise anomositik tip stomalara ve bulliform hücrelerine rastlanmıştır. Morfolojik incelemelerde bitki boyunun $15-40 \mathrm{~cm}$ arasında değiştiği, yapraklarda ana damar baskınlığının olmadığı ve ortalama çiçek sayısının 5-20 olduğu belirlenmiştir. Mikromorfolojik incelemelerde yaprak alt ve üst yüzeyde sitriat (çizgili) süslemelere rastlanmıştır. Ayrıca yaprak üst yüzeyinde papillere rastlanmıştır. Çalışmamız sonucunda $S$. satyrioides türüne ait tüm anatomik, morfolojik ve mikromorfolojik özellikleri detaylı bir şekilde ortaya konulmuştur.

Anahtar Kelimeler- Anatomi, Morfoloji, Monotipik, Orchidaceae, SEM

1*Sorumlu yazar iletişim: mkakbulut@comu.edu.tr (https://orcid.org/0000-0002-3362-785X)

Park ve Bahçe Bitkileri Bölümü, Çanakkale Onsekiz Mart Üniversitesi, Çanakkale, Türkiye

2İletişim: senay.sungu@omu.edu.tr (https://orcid.org/0000-0003-4993-988X)

Biyoloji Bölümü, Ondokuz Mayıs Üniversitesi, Samsun, Türkiye

3Iletişim: gsenel@omu.edu.tr (https://orcid.org/0000-0003-4993-988X)

Biyoloji Bölümü, Ondokuz Mayıs Üniversitesi, Samsun, Türkiye 


\title{
The Anatomical, Morphological and Micromorphological Properties of Monotypic Species Steveniella satyrioides
}

\begin{abstract}
The anatomy, morphology and micromorphology of Steveniella satyrioides distributed in Turkey and from Orchidaceae which is one of the two largest families of angiosperms were examined in our study. S. satyrioides is monotypic and its flower structure is similar to the species of Orchis genus. For anatomical observation, the transversal sections were taken from the roots, stems and leaves of the specimens with microtome. The speciment were observed on their natural areas and the measurement were performed on these specimens for morphological analysis. Micromorphological investigations on the leaves of herbarium specimens were also made using scanning electron microscope (SEM). Anatomical examinations revealed single-row exodermis cells on the outer part of the root and pit at the center. The mean number of xylem arms was 8-9. Perivascular sclerenchymatic sheath was found on the stem and anomocytic stomata and bulliform cells were found on the leaves. Morphological investigations revealed that plant height ranged from $15-40 \mathrm{~cm}$, that midrib was not found and that the average number of flowers was 5-20. Micromorphological investigations revealed striate ornamentations on the upper and lower leaves. As a result of study, all of the anatomical, morphological and micromorphological features of monotypic S. satyrioides have been revealed in detailed.
\end{abstract}

Keywords- Anatomy, Morphology, Monotypic, Orchidaceae, SEM 


\section{GİRIŞ}

Steveniella, Orchidaceae familyasının monotipik bir cinsidir. Karadeniz’in kuzey ve güneyi, Kuzey İran ile Kafkaslar bölgesinde yayılış göstermektedir [1,2]. İğne yapraklı ve yaprak döken ormanlar, Quercus çalılıkları ve ormanlar arasındaki açıklıklar doğal yetişme ortamlarıdır [2]. Türe ait bireyler deniz seviyesinden başlayıp 1300 metreye kadar olan yüksekliklerde rastlanabilmektedir [2]. Geçmişte oluşturduğu popülasyonlardaki birey sayısı oldukça fazla olan Steveniella satyrioides [3], günümüzde yayılış gösterdiği alanlarda oldukça seyrek olarak rastlanmaktadır [4]. Küçük yuvarlak yumrulara sahiptir ve ortalama en fazla 35 cm boylanabilmektedir [5]. Çiçek yapıları her ne kadar Orchis ile benzese de Steveniella'nın bir adet bazal yaprağa sahip olması belirgin ayırt edici bir özelliğidir [5].

Steveniella satyrioides üzerinde yapılan çalışmalar daha çok türün polinasyonu üzerinedir $[6,7,8]$. Tür nektarsız olup polinasyonda koku ve labellum rengi etkin rol oynamaktadır $[6,9,10,11]$. Familya üzerinde genel anatomik çalışmalar yapılmasına karşın $[12,13]$ tür üzerinde detaylı anatomik çalışma bulunmamaktadır. Familyaya ait bitkiler üzerinde farklı alanlarda da birçok çalışmalar yapılmıştır. Bu çalışmaların başında özellikle taksonomik çalışmalar gelmektedir $[14,15,16]$. Yapılan bu çalışmalara rağmen familyanın taksonomik ve sistematik yönden ortaya çıkan problemleri henüz tam olarak çözülememiştir. Bunun başlıca sebepleri, familyaya ait türlerin geniş bir coğrafyada yayılış göstermesi ve çiçeklerinin birçok varyasyona sahip olmasıdır $[17,18]$. Bu nedenle yanlış bitki teşhisleri ve kişilere göre değişen farklı taksonomik uygulamalar sonucunda familya açısından problemler daha da artmaktadır [19]. Bu çalışma ile monotipik bir cinse ait olan Steveniella satyrioides türünün anatomik, morfolojik ve mikromorfolojik özelliklerinin ortaya konulması amaçlanmıştır.

\section{MAteryal VE Metod}

Steveniella satyrioides türüne ait örnekler, bitkilerin çiçekli oldukları dönem olan Nisan ve Haziran ayları arasında Karadeniz Bölgesi’ndeki farklı lokalitelerden toplanmıştır. Lokaliteler aşağıda listelenmiştir. Toplanan materyallerin bir kısmı herbaryum örneği haline getirilmiş, bir kısmı da \%70'lik alkol içerisinde stok örnek haline getirilmiştir. Morfolojik özelliklerinin belirlenmesinde arazide gözlemler yapılmış ve herbaryum örnekleri üzerinden incelemeler yapılmıştır. Belirlenen karakterler ortalama 10 örnek üzerinden ölçülmüştür. Örneklerin anatomik özelliklerinin belirlenmesinde kök, gövde ve yaprak gibi kısımlarından alınan örnekler parafine gömülerek mikrotom yardımıyla kesitler alınmıştır. Örnekler metal kalıplara, $60^{\circ} \mathrm{C}^{\prime}$ lik etüvde sıvı hale getirilen parafin ile birlikte yerleştirilerek parafin bloklar halinde hazırlanmıştır. Bu şekilde parafin metoduyla hazırlanan örneklerden mikrotom vasıtasıyla 15-20 $\mu$ kalınlığında kesitler alınmıştır. Alınan kesitler Zeiss AxioLab A1 mikroskobu ve Zeiss Axiocam 105 görüntüleme sistemi ile incelenmiştir. Anatomik kesitler alınırken lokalite farklılıkları dikkate alınmış ve her özellik için aynı mikroskop kullanılarak ortalama 30 ölçüm yapılmıştır. Kesitlerde inceleme ortamı olarak gliserin kullanılıp preparatların kenarları parafinle kapatılarak yarı-kalıcı preparatlar hazırlanmıştır. Ayrıca araştırma konusu olan türün yaprak yüzeyleri mikromorfolojik olarak incelenmiştir. Yaprakta alt ve üst yüzeyde bulunan epiderma ve stoma hücrelerinin genel görünüşleri belirlenmiştir. Elektron mikroskop çekimleri için örnekler stublar üzerine çift taraflı karbon bant ile yapıştırılarak 12,5-15 nm altın-paladyum ile kaplanmıştır (SEM coating system, SC7620). İnceleme ve çekimler JEOL JMS-7001F Taramalı Elektron Mikroskobunda (SEM) 5-15 KV'lik voltaj ile yapılmıştır. Taksonlara ait belirlenen anatomik karakterlere nümerik analizler yapılmıştır. Analizlerde SPSS 22 paket programı kullanılmıştır [20]. Morfolojik karakterler için ortalama değerler ve grafikler Microsoft Excel programı ile oluşturulmuştur. Resimler üzerinde yapılan düzenlemelerde Photoshop CS6 programı kullanılmıştır.

L1: Kurupelit/Samsun, Mayıs 2015, Yaprak döken ormanlar, Quercus ormanlar1, 210m, Omubh 3041

L2: Ünye/Ordu, Mayıs 2015, Yaprak döken orman kenarları, 90m, Mka 50

L3: Bafra/Samsun, Mayıs 2015, Yaprak döken orman kenarları, 120m, Mka 40

\section{BULGULAR}

Yapılan morfolojik incelemelerde bitki ortalama 15-40 cm uzunluğundadır. Yaprak sayısı bir ve yaprak şekli ligulat-lanseolatdır. Yapraklarda ana damar baskın değildir ve damarlanma retikulattır. Yaprak bazal olup yapraklarda benek bulunmamaktadır. Gövde yuvarlak, çiçek durumu ise seyrek spikadır. Çiçekler yeşilimsi mor, labellum üç lobludur ve spur sakkattır (Şekil 1). Kök tuberleri 2 adet ve ovattır. Anatomik incelemelerde kökte ekzodermis ve öz belirlenmiştir. Ksilem kol sayısı ortalama altıdır ve kökte kristallere rastlanmıştır (Şekil 2). 


\begin{tabular}{|c|c|c|}
\hline & $\begin{array}{l}\text { BŞEÜ Fen Bilimleri Dergisi } \\
6(2), 573-584,2019\end{array}$ & $\begin{array}{r}\text { BSEU Journal of Science } \\
\text { DOI: } 10.35193 / \text { bseufbd.603395 }\end{array}$ \\
\hline $\begin{array}{l}\text { B̈LECIKSEYHEDEBALI } \\
\text { ONIVERSITES }\end{array}$ & & e-ISSN: 2458-7575 (http://dergipark.gov.tr/bseufbd) \\
\hline
\end{tabular}

Gövde de perivasküler sklerenkimatik kın bulunurken kristal ve tüye rastlanmamıştır (Şekil 3). Yapraklarda ise yaprak alt yüzeylerinde stomalara rastlanırken üst yüzeylerde stomaya rastlanmamıştır. Stoma tipi anomositiktir. Yapraklarda bulliform hücreleri, hava boşluğu ve kristal bulunmaktadır (Şekil 4). Mikromorfolojik incelemelerde yaprak üst ve alt yüzey hücre şekilleri uzamış poligonal olarak belirlenmiştir. Yaprak yüzey süslemeleri hem alt hem de üst yüzeyde sitriattır (çizgili) (Şekil 5).Bitkinin kökünden alınan enine kesitlerde en dış kısımda tek sıralı epidermis tabakası yer almaktadır. Epidermis hücreleri ortalama $54,57 \mu \pm \times 40,42 \pm 8,44 \mu$, tek tabakadan oluşan ekzodermis hücreleri ise ortalama $71,03 \mu \pm 16,28 \times 46,89 \pm 10,37 \mu$ boyutlarındadır. Epidermisin

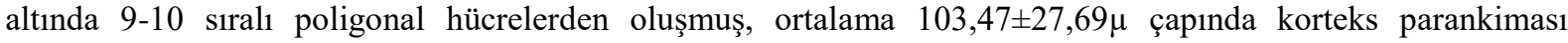
hücreleri yer almaktadır. Korteks hücrelerinde kristal kumu belirlenmiştir. Hücrelerde fungusa (endomikhoriza) rastlanmıştır. Endodermis tabakasını oluşturan hücreler belirgin, ortalama $71,71 \pm 20,29 \mu \times 42,40 \pm 12,01 \mu$ boyutlarında, periskl hücreleri ise ortalama $27,80 \pm 6,86 \mu$ çapındadır. Ksilem kollarının sayısı 8-9 dur. Trake hücreleri ortalama $19,30 \pm 5,66 \mu$, kalburlu borular ise ortalama 20,35 $\pm 5,66 \mu$ çapındaki hücrelerden oluşmaktadır. Merkezde öz kısmı bulunmakta ve ortalama 40,02 $\pm 10,42 \mu$ çapında poligonal şekilli hücrelerden oluşmaktadır (Şekil 2, Şekil 6).

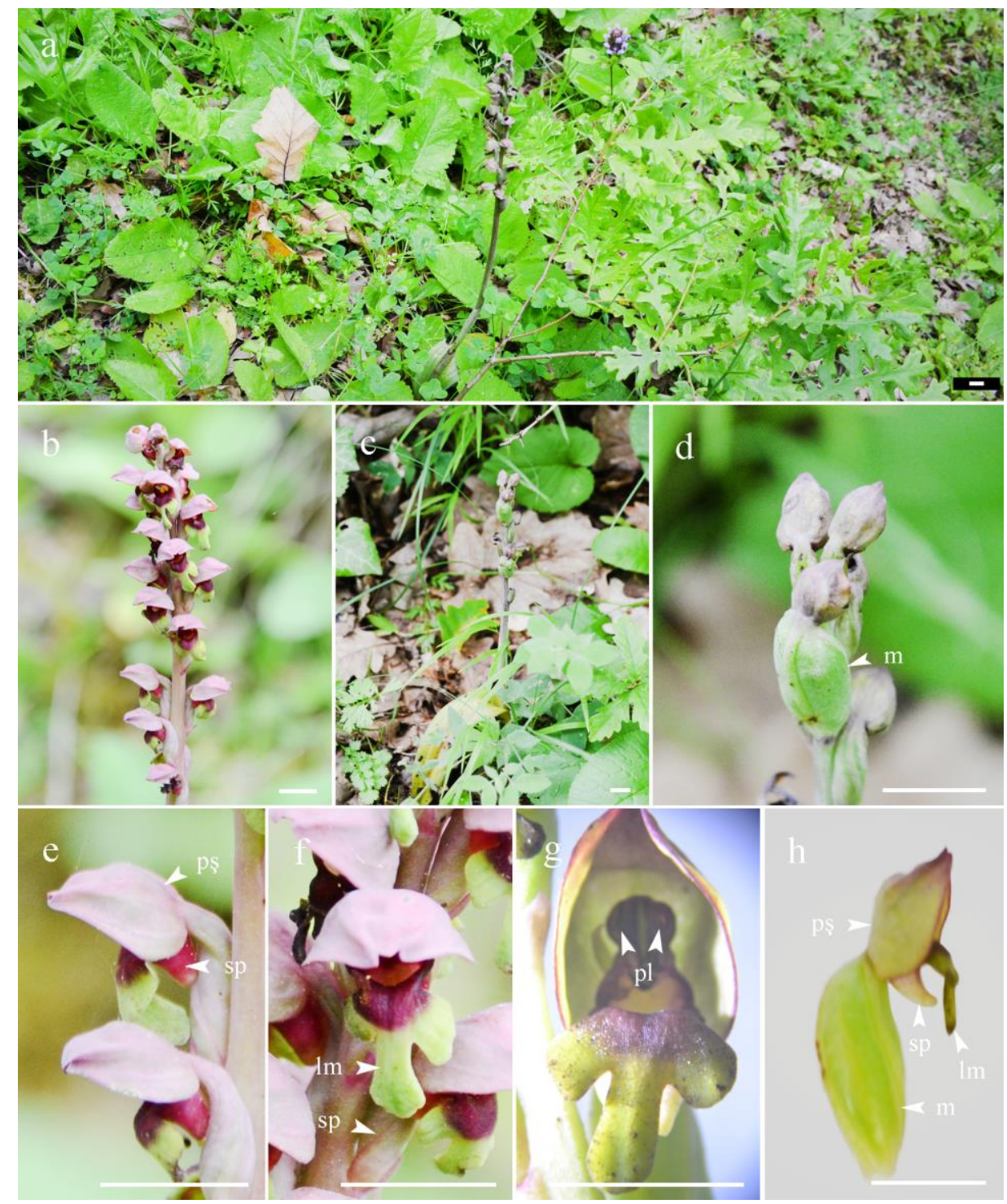

Şekil 1. S. satyrioides türünün morfolojik görünümü. a-c) genel görünüşü, d) meyve yapısı, e-h) çiçek yapısı, m: meyve, sp: spur, pş: periant şapkası, lm: labellum, pl: polinyum, skala bar: $1 \mathrm{~cm}$. 
BȘEÜ Fen Bilimleri Dergisi

$6(2), 573-584,2019$
BSEU Journal of Science DOI: $10.35193 /$ bseufbd.603395

Örneklerden alınan gövde enine kesitlerinde diş yüzeyde tek sıralı epidermis tabakası bulunmaktadır. Epidermis, ortalama $39,06 \pm 5,47 \mu \times 42,12 \pm 6,6 \mu$ boyutlarında hücrelere sahiptir. Epidermisin altında $12-13$ siralı korteks parankiması yer almaktadır. Korteks parankiması hücreleri ortalama $44,57 \pm 7,73 \mu$ çapındaki izodiyametrik-poligonal hücrelerden oluşmaktadır. Trake hücreleri ortalama $18,09 \pm 3,96 \mu$, kalburlu boru hücreleri ise ortalama $15,28 \pm 3,23 \mu$ çapındadır. Merkezde geniş bir öz boşluğu yer almaktadır. Öz bölgesinin iletim demetleri altında kalan hücrelerinin boyutları ortalama $93,73 \pm 20,52 \mu$ çapındadır (Şekil 3, Şekil 6). Bitkinin yaprağından alınan enine kesitlerde alt ve üst yüzeyde tek srralı epidermis hücreleri bulunmaktadır. Alt ve üst epidermis hücrelerinin büyüklükleri birbirinden oldukça farklıdır. Üst epidermis hücreleri ortalama $133,30 \pm 37,73 \mu \times 57,91 \pm 11,55 \mu$ boyutlarında, alt epidermis hücreleri ise ortalama $44,23 \pm 11,31 \mu \times 48,14 \pm 7,53 \mu$ boyutlarındadır. Bulliform hücreleri $100,46 \pm 31,89 \mu \times 147,18 \pm 28,37 \mu$ boyutlarındadır. Yaprakların üst ve alt

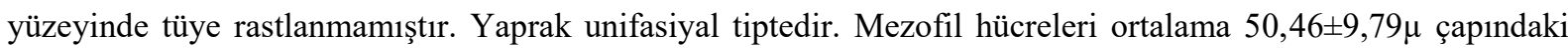
parankima hücrelerinden oluşmaktadır. Kristal idiyoblastlarında rafit kristaller belirlenmiştir (Şekil 4, Şekil 6).
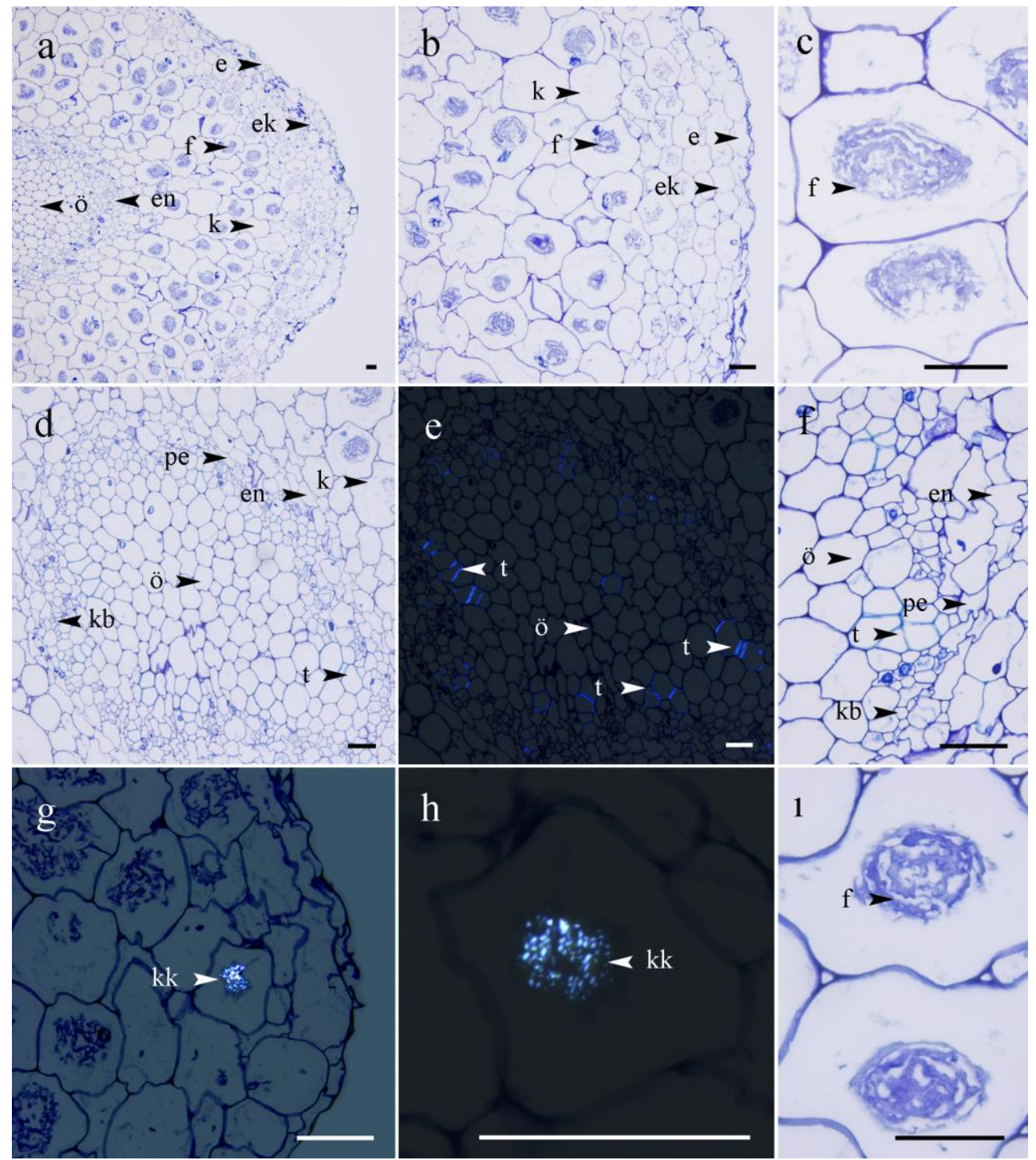

Şekil 2. S. satyrioides türünün kök anatomisi. a) genel görünüș, b) korteks bölgesi, c,1) kortekste bulunan funguslar, d-e) öz bölgesi, f) korteks-öz geçiş bölgesi, g-h) kristal kumları, e, g-h) polarize mikroskop çekimleri, e: epidermis, ek: ekzodermis, k: korteks, en: endodermis, ö: öz, f: fungus, pe: periskl, t: trake, kb: kalburlu boru, kk: kristal kumu, skala bar: $50 \mu$ 


\begin{tabular}{|c|c|c|}
\hline & $\begin{array}{l}\text { BŞEÜ Fen Bilimleri Dergisi } \\
6(2), 573-584,2019\end{array}$ & $\begin{array}{r}\text { BSEU Journal of Science } \\
\text { DOI: } 10.35193 / \text { bseufbd.603395 }\end{array}$ \\
\hline $\begin{array}{l}\text { BiLLECIKSEYHEDEBALI } \\
\text { UNIVERSITES }\end{array}$ & & e-ISSN: 2458-7575 (http://dergipark.gov.tr/bseufbd) \\
\hline
\end{tabular}

Yüzeysel kesitlerde yaprak üst ve alt yüzeyinde bulunan epiderma hücreleri düz çeperlidir. Stomalar anomositik tip ve ortalama $59,27 \pm 6,09 \mu \times 48,48 \pm 6,99 \mu$ boyutlarındadır. Yaprağın üst yüzeyinde $1 \mathrm{~mm}^{2}$ de ortalama 96 epidermis hücresi bulunmaktadır. Yaprak alt yüzeyinde $1 \mathrm{~mm}^{2}$ 'de ortalama $32 \pm 2,5$ stoma ve 152 $\pm 9,4$ epidermis hücresi belirlenmiştir (Şekil 5, Şekil 6).

Mikromorfolojik incelemelerde yaprak alt ve üst yüzeyinde bulunan hücrelerin uzamış poligonal olduğu gözlemlenmiştir. Ayrıca yüzeyde bulunan desenlenmeler hem alt hem de üst yüzeyde sitriat (çizgili) olarak belirlenmiştir. Yaprak üst yüzeyinde papil yapılarına rastlanmıştır (Şekil 5e-f).

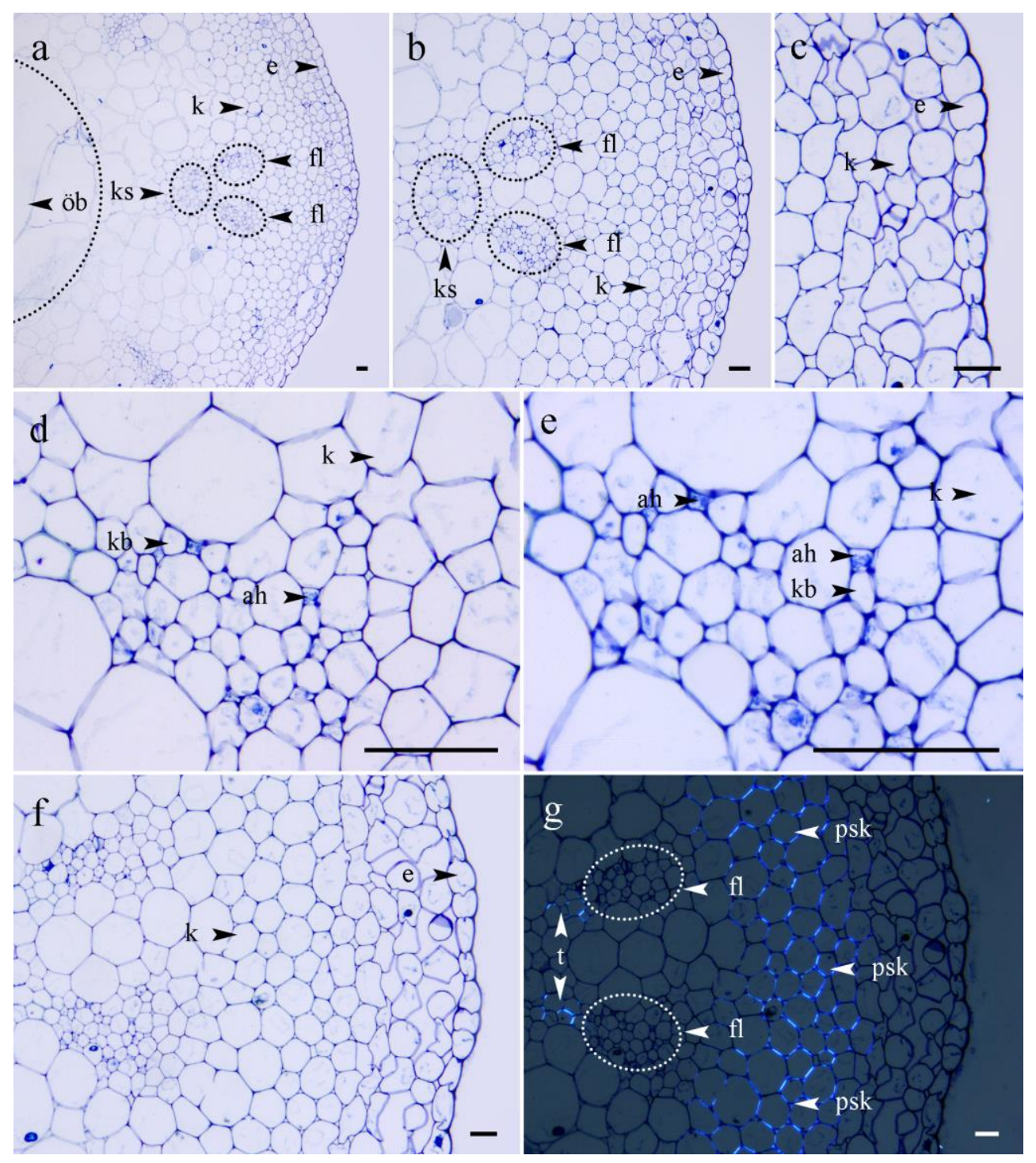

Şekil 3. S. satyrioides türünün gövde anatomisi. a-c) genel görünüş, d-e) iletim demeti f-g) genel görünüş, g) polarize mikroskop çekimleri, e: epidermis, k: korteks, ks: ksilem, fl: floem, f: fungus, pe: periskl, t: trake, kb: kalburlu boru, kk: kristal kumu, ah:arkadaş hücresi, skala bar: $50 \mu$. 


\section{SONUÇLAR}

$\mathrm{Bu}$ araştırma ile monotipik bir cinse ait olan Steveniella satyrioides türünün morfolojik, anatomik ve mikromorfolojik özellikleri ortaya konulmuştur. Türün labellum yapısı üç loblu ve çiçek rengi çoğunlukla yeşilimsi mordur. Renk bitkilerde genetik olarak kontrol edilmektedir [21]. Ancak çevresel faktörlerin renkler üzerinde az çok etkisi bulunmaktadır. Gajewski [22], bitkilerde parlaklığa genetik ve diğer faktörlerin etkisinin az olduğunu, çevresel faktörlerin ise bu konuda daha fazla etkili olduğunu belirtmiştir. Türe ait yapraklar bazal yaprak şeklindedir. Orchidaceae familyasında bazal yaprak yapısına sıklıkla rastlanılmaktadır [23]. Davis [24], familyada yaprakların bazal ya da gövdede, nadiren de olsa bulunmadığını ifade etmiştir.

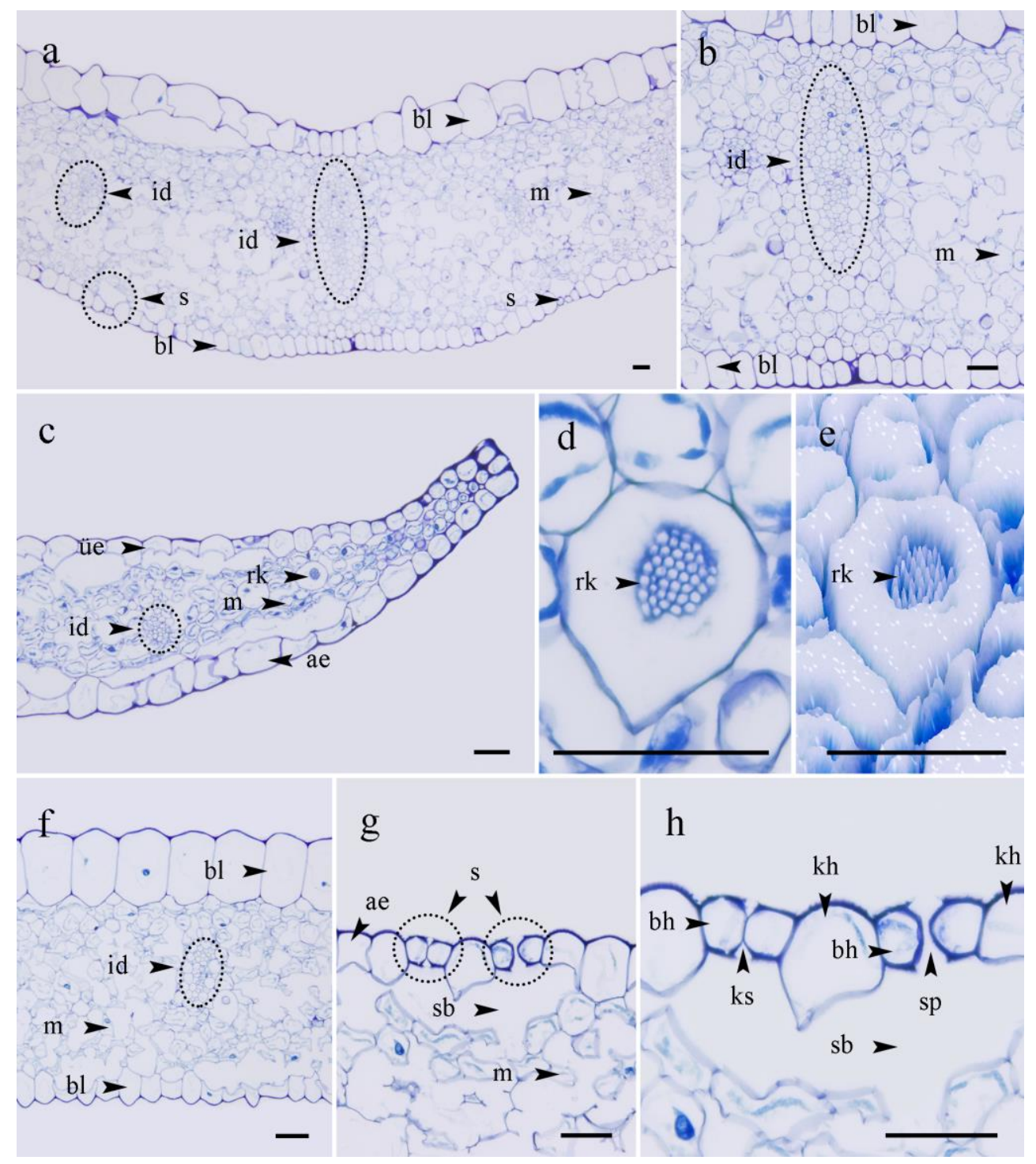

Şekil 4. S. satyrioides türünün yaprak anatomisi. a) genel görünüș, b) iletim demeti c) yaprak kenar genel görünüşü, d-e) rafit kristaller, f) bulliform hücreleri, g-h) stoma yapıları, üe: üst epidermis, ae: alt epidermis, bl: bulliform hücresi, id: iletim demeti, m: mezofil, s: stoma, rk: rafit kristal, sb: stoma boşluğu, ks: kapalı stoma, sp: stoma poru, bh: bekçi hücresi, kh: komşu hücresi, skala bar: $50 \mu$.

Anatomik incelemelerde kökte ekzodermis tabakasına rastlanmıştır ve 9-10 sıralı korteks tabakası belirlenmiştir. Korteks hücre tabakalarının sayısı farklı çevresel koşullarla değişmemekte, ancak olgunlaşma hızı 
hücrelerin boyutu ve hücre sıra sayısını değiştirilebilmektedir [25, 26]. Kök ve yapraklarda kristallere rastlanmıştır. Kristaller çoğunlukla rafit demetleri şeklindedir. Aybeke ve ark., [27] orkideler üzerinde yapmış oldukları çalışmada birçok türün kök, gövde ve yapraklarında rafit kristallere rastlamıştır. Gövdede perivasküler sklerenkimatik kın ve yapraklarda bulliform hücreleri belirlenmiştir. Vejetatif organlar üzerinde yapılan anatomik çalışmalar, yakın ilişkili gruplara destek sağlayan karakterler ortaya koymaktadır [28].

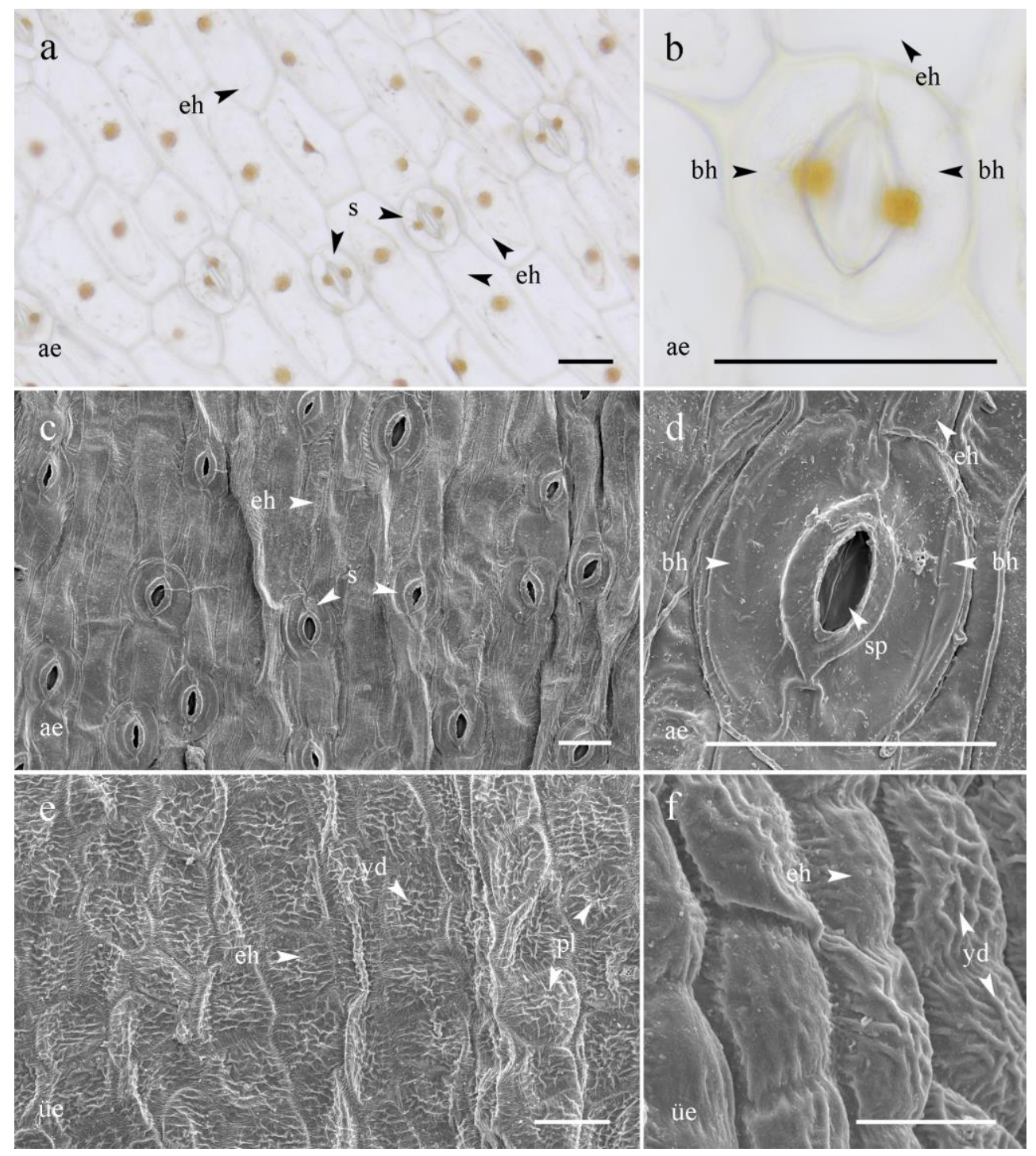

Şekil 5. S. satyrioides türünün yaprak anatomisi ve mikromorfolojisi. a-d) yaprak alt yüzey genel görünüşü, e-f) yaprak üst yüzey genel görünüşü, üe: üst epidermis, ae: alt epidermis, eh: epidermis hücresi, s: stoma, bh: bekçi hücresi, sp: stoma poru, yd: yüzey desenleri, pl: papil yapıları, skala bar: $50 \mu$.

Türde belirlenen mikromorfolojik özellikler yaprak yüzeyi ile ilgilidir. Bazı mikromorfolojik özellikler taksonlar arasında ayırt edici ve güvenilir karakterler olarak değerlendirilmektedir [29, 30]. Yapraklarda papillar yapılara, uzamış poligonal hücrelere ve sitriat (çizgili) yüzey desenlenmelerine rastlanmıştır. Şenel ve ark., [31] yapmış oldukları çalışmada benzer sonuçlara ulaşmış ve türün yaprak yüzeyinde sitriat (çizgili) desenlenmelere rastlamışlardır. 
Sonuç olarak araştırmamızda elde edilen bulguların cins üzerinde daha sonra yapılacak çalışmalar için yol gösterici olabileceği düşünülmektedir. Ayrıca ortaya konulan karakterlerin cinsin taksonomisine katkı sağlaması beklenmektedir.

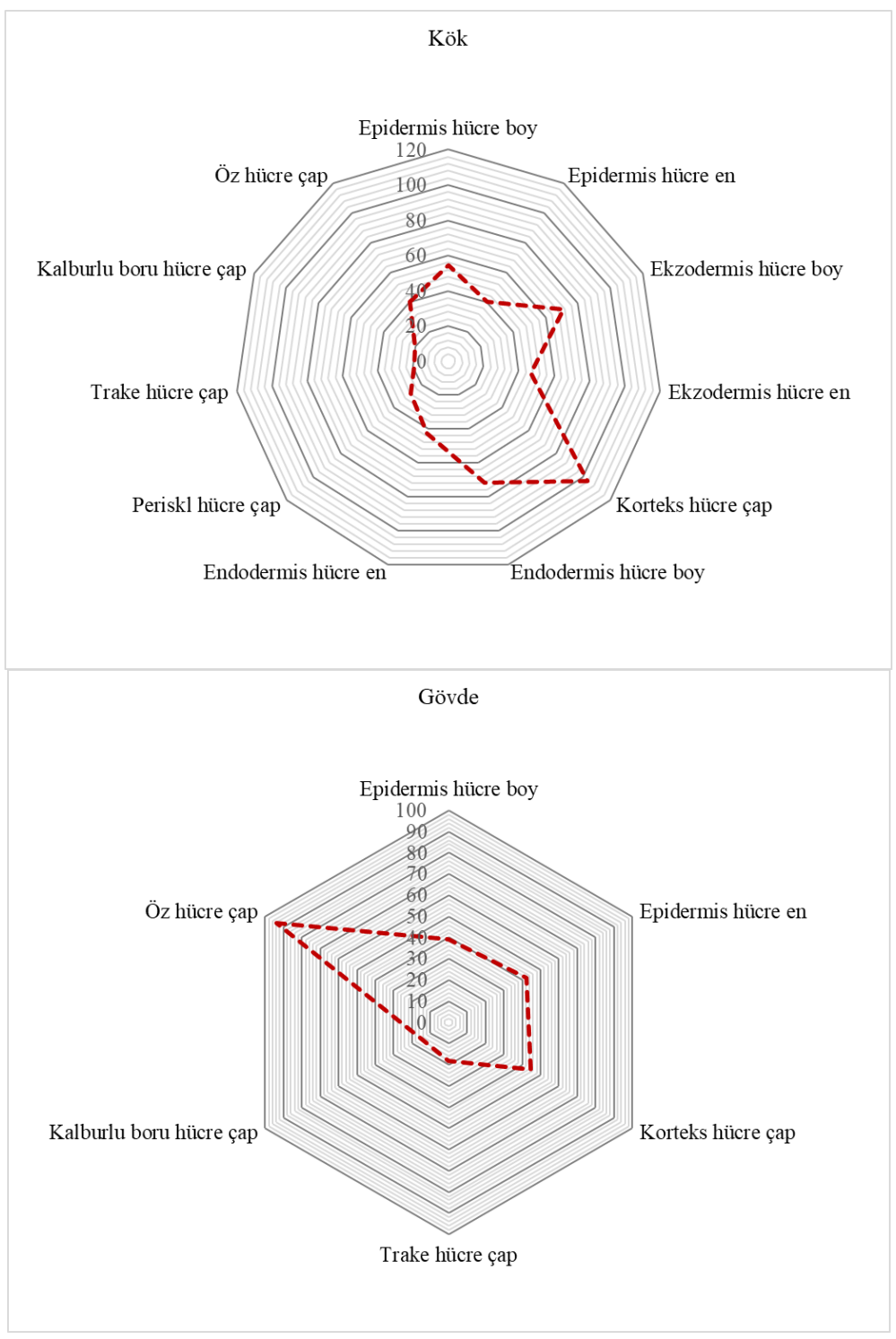




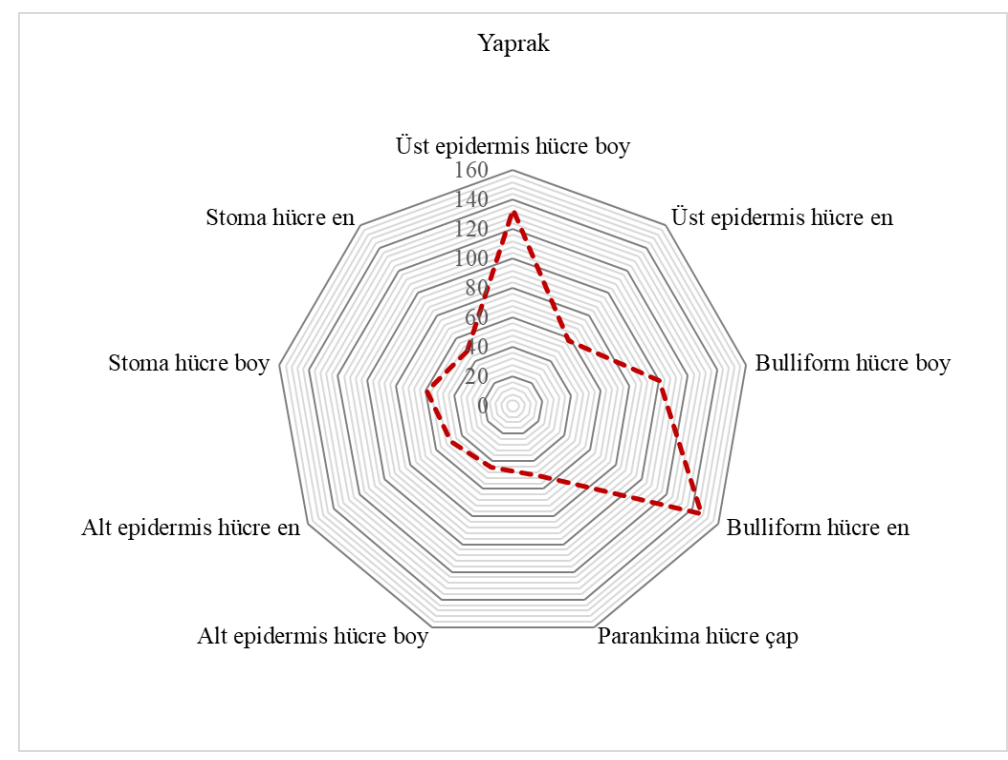

Şekil 6. S. satyrioides türünün kök, gövde ve yaprak anatomik ölçümleri.

\section{TEŞEKKÜR} (114Z702).

Bu çalışma, Türkiye Bilimsel ve Teknolojik Araştırma Kurumu (TÜBİTAK) tarafından desteklenmiştir

\section{KAYNAKLAR}

[1] Nevski, S. A. (1935). Fam. 36. The orchids-Orchidaceae Lindl. Pages 589-730 in V. L. Komarov (ed.), Flora USSR (in Russian). Moskva - Leningrad: Publ. Acad. Sci. USSR, 4.

[2] Renz, J., \& Taubenheim, G. (1984). Dactylorhiza Necker ex Nevskié. Flora of Turkey and the East Aegean Islands Vol. 8. Editör: Davis, P.H. Edinburgh: Edinburgh University Press.

[3] Vanykov, I. (1914). Notes on Orchis satyrioides Stev. (in Russian). Tr. Juryevskogo Botan, Sada Imperatorskogo Juryevskogo Universiteta 15: 292-295.

[4] Fateryga, A. V., Ivanov, S. P., \& Fateryga, V. V. (2013). Pollination ecology of Steveniella satyrioides (Spreng.) Schltr. (Orchidaceae) in Ayan Natural Landmark (the Crimea). Укр. ботан. журн, 70(2), 195201.

[5] Sezik, E. E. (1984). Orkidelerimiz: Türkiye'nin orkideleri. Sandoz kültür yayınları.

[6] Nazarov, V. V. (1995). Pollination of Steveniella satyrioides (Orchidaceae) by wasps (Hymenoptera, Vespoidea) in the Crimea, Lindleyana, 10(2), 109-114.

[7] Brodmann, J., Twele, R., Francke, W., Luo Yi-bo, L., Xi-qiang, S., \& Ayasse, M. (2008). Orchid mimics honey bee alarm pheromone in order to attract hornets for pollination, Current Biology, 18, 740-744.

[8] Brodmann, J., Twele, R., Francke, W., Yi-Bo, L., Xi-qiang, S., \& Ayasse, M. (2009). Orchid mimics honey bee alarm pheromone in order to attract hornets for pollination, Current Biology, 19(16), 1368-1372.

[9] Proctor, M., Yeo, P., \& Lack, A. (1996). The Natural History of Pollination, 2nd ed. London, UK: Harper Collins Publishers. 
[10] Cozzolino, S., \& Widmer, A. (2005). Orchid diversity: an evolutionary consequence of deception? Trends Ecology and Evolution 20: 487-494.

[11] Kowalkowska, A. K., Margonska, H. B., Kozieradzka-Kiszkurno, M., \& Bohdanowicz, J. (2012). Studies on the ultrastructure of a threespurred fumeauxiana form of Anacamptis pyramidalis, Plant Systematics and Evolution, 298: 1025-1035.

[12] Şeker, Ş. S., Akbulut, M. K., \& Şenel, G. (2016). Labellum micromorphology of some orchid genera (Orchidaceae) distributed in the Black Sea region in Turkey, Turkish Journal of Botany, 40(6), 623-636.

[13] Şenel, G., Akbulut, M. K., \& Şeker, Ş. S. (2019). Comparative anatomical properties of some Epidendroideae and Orchidoideae species distributed in NE Turkey, Protoplasma, 256(3), 655-668.

[14] Bateman, R. M. (2001). Evolution and classification of European orchids: insights from molecular and morphological characters, Journal Europäischer Orchideen, 33: 33-119.

[15] Shipunov, A. B., \& Bateman R. M. (2005). Geometric morphometrics as a tool for understanding Dactylorhiza (Orchidaceae) diversity in European Russia, Biological Journal of the Linnean Society, 85: 112.

[16] Inda, L. A., Pimentel, M., \& Chase, M. W. (2010). Chalcone synthase variation and phylogenetic relationships in Dactylorhiza (Orchidaceae). Botanical Journal of the Linnean Society, 163, 155-165.

[17] Arditti, J. (1977). Orchid biology, reviews and perspectives. Ithaca: I. Comstock publishing associates, Cornell University Press.

[18] Dressler, R. L. (1993). Phylogeny and Classification of the Orchids Family. Portland: Dioscorides Press.

[19] Nordström, S., \& Hedrén, M. (2009). Genetic diversity and differentiation of allopolyploid Dactylorhiza (Orchidaceae) with particular focus on the D. majalis ssp. traunsteineri lapponica complex. Biological Journal of the Linnean Society, 97: 52-67.

[20] IBM Corp. Released (2013). IBM SPSS Statistics for Windows, Version 22.0. Armonk, NY: IBM Corp.

[21] Quattrocchio, F., Wing, J., van der Woude, K., Souer, E., de Vetten, N., Mol, J., \& Koes, R. (1999). Molecular analysis of the anthocyanin 2 gene of petunia and its role in the evolution of flower color, Plant Cell 11(8), 1433-1444.

[22] Gajewski, M., Radzonowska, J., Danilcenko, H., Jariene, E., \& Cerniauskiene, J. (2008). Quality of pumpkin cultivars in relation to sensory characteristics, Not Botanicae Horti Agrobotanici Cluj-Napoca, 36,73-79

[23] Şenel, G., Şeker, Ş. S., Akbulut, M. K., \& Akçin, Ö. E. (2018). An integrative anatomical, morphological, micromorphological and molecular approach to Turkish Epidendroid and Orchidoid species (Orchidaceae), Nordic Journal of Botany, 36(7), e01700.

[24] Davis, P. H. (1965). Flora of Turkey and the east Aegean islands, Vol. 10. Edinburgh: Edinburgh University Press.

[25] Dycus, A. M., \& Knudson, L. (1957). The role of the velamen of the aerial roots of orchids, Botanical Gazette, 78-87.

[26] Oliveira, V. D. C., \& Sajo, M. D. G. (1999). Anatomia foliar de espécies epífitas de Orchidaceae, Revista Brasileira de Botânica, 22 (3), 365-374. 
[27] Aybeke, M., Sezik, E., \& Olgun, G. (2010). Vegetative anatomy of some Ophrys, Orchis and Dactylorhiza (Orchidaceae) taxa in Trakya region of Turkey, Flora-Morphology, Distribution, Functional Ecology of Plants, 205(2), 73-89.

[28] Stern, W. L., \& Judd, W. S. (2001). Comparative anatomy of Catasetiinae (Orchidaceae), Botanical Journal of Linnean Society, 136, 153-178.

[29] Akçin, T. A., Özdener, Y., \& Akçin, A. (2009). Taxonomic value of seed characters in orchids from Turkey, Belgian Journal of Botany142 (2), 124-139.

[30] Gamarra, R., Ortúñez, E., Cela, P. G., \& Guadaño, V. (2012). Anacamptis versus Orchis (Orchidaceae): Seed micromorphology and its taxonomic significance, Plant Systematics and Evolution, 298, 597-607.

[31] Şenel, G., Şeker, Ş. S., Akbulut, M. K., \& Akçin, Ö. E. (2018). An integrative anatomical, morphological, micromorphological and molecular approach to Turkish epidendroid and orchidoid species (Orchidaceae). Nordic Journal of Botany, 36(7), e01700. 